\title{
Terrorism Abroad and Migration Policies at Home
}

\author{
VINCENZO BOVE \\ University of Warwick
}

\author{
AND \\ TOBIAS BÖHMELT \\ University of Essex \\ AND \\ ENZO NUSSIO \\ ETH Zürich
}

Do security concerns lead to more restrictive immigration policies? In this article, we contend that transnational influences can shape legislative output on immigration at home. Terrorist attacks in a neighboring country affect the salience of security concerns in the focal state, the policy solutions for addressing them, and the political will to implement these changes. In proximity of countries targeted by terrorism, politicians have specific incentives to manipulate immigration regulations following pressure from public opinion, for political opportunism or in anticipation of their neighbors' policy choices. Using data on 33 OECD countries, we find that proximity to targeted countries leads to the implementation of a more restrictive migration policy regime. The public's common perception of a linkage between migration and terrorism thus has important policy consequences.

Keywords: Terrorism; Immigration; National Migration Policies; OECD 
Facilitating orderly and safe migration of people through the implementation of planned and well-managed migration policies is a core item of the 2030 Agenda for Sustainable Development, adopted by all UN member states in 2015. Immigration has the potential to positively contribute to the economic prosperity of destination countries (Bove and Elia 2017), but, at the same time, it can create tensions between immigrants and the native populations as well as between immigrant communities and state actors, particularly when resources are scarce (Dancygier 2010). Not surprisingly, the substantial increase in transnational migration flows worldwide, particularly in the last two decades, has brought immigration laws to the forefront of a contentious political debate.

Migration policies describe how nations view the movement of people across borders, and how states define and regulate international migration accordingly (Kritz 1987). Migration laws vary widely across countries and over time within the same state (Cerna 2016; Givens and Luedtke 2005; Helbling and Kalkum 2018; Helbling and Michalowski 2017; Howard 2009; Joppke 2017; Koopmans et al. 2012; Ruhs 2015). Scholars recently began to collect more comprehensive data to shed light on the general development of these legislations and their various components (Beine et al. 2016; Helbling et al. 2017; Helbling and Kalkum 2018).

We contribute to the literature on immigration laws by contending that cross-national variation in the demand for policy closure should be evaluated against the background of wider security concerns. Political leaders in Europe and elsewhere are increasingly associating the risk of terrorism to immigration. For example, the Polish President, Andrzej Duda, stated in 2017 that "there is no doubt that the growing wave of terrorism is linked to migration" and that "migrants pose a security threat" (Radio Poland, 15/09/2017). Simultaneously, news about terrorist attacks can also trigger more negative views of immigrants among the general public (Finseraas et al. 2011; Legewie 2013; Schüller 2016). Governments often sought to justify barriers to migration based on national security concerns 
and used new migration policies as counterterrorism methods. After 9/11, most EU countries strengthened their border control and tightened their migration policies by making it more difficult for potential migrants to legally move to another country (d'Appollonia and Reich 2008). Just few days after the 2015 attacks in Paris, EU states from Sweden to Slovenia have enacted new border controls, erected border fences, or discussed new ways to screen and register migrants out of fear that Islamist terrorists might infiltrate migrant flows (Lyman and Smale 2015). And the Trump administration has justified, at least rhetorically, a new range of measures by invoking the risk of terrorism in the aftermath of attacks in France, the UK, and Egypt, among others (Bump 2019). In light of this, we focus on a transnational influence on migration policy and argue that terrorist attacks in other countries shape legislative output on migration in a focal state.

This research provides an important empirical contribution and differs in two key aspects from earlier studies. On one hand, there is evidence that terrorism leads to a tightening of antiterrorism regulations in targeted states (Avdan 2014b; Avdan 2014a; Epifanio 2016; Helbling and Meierrieks 2018). Yet, we claim that proximity to the targeted country can significantly and substantively affect also migration policies at home, even when terrorism abroad may not necessarily pose a real or direct threat to a domestic audience. Extant work largely neglected how security threats in nearby regions drive support for more restrictive immigration laws. On the other hand, non-domestic, transnational influences have generally been ignored in this context except for the influential works on policy-to-policy diffusion (Gilardi 2010).

In addition to tangible terrorist threats in the home country (Balcells and Torrats-Espinosa 2018; Epifanio 2016), we argue that terrorism in neighboring states move the security issue to the top of the political agenda and prompt policy entrepreneurs to propose migration policies in response (Kingdon 2003). Public demands often translate into actual legislative outputs and democratic politicians, interested in retaining power, take into account citizens' concerns (Anderson et al. 2017; Downs 1957). When choosing policy solutions to address the threat of 
terrorism in the vicinity, politicians consider the costs of their decisions in terms of their voter base. They may restrict migration policy on the basis of three main motivations: pressure from public opinion, which tends to turn more migration-unfriendly after attacks; political opportunism, as an attack may provide them with a window of opportunity to enact policies they always wanted; and anticipation of their neighbors' policy choices, given that they want to avoid being the weakest target in the vicinity. In proximity of countries targeted by terrorism, migration policy is thus an ideal field of engagement for politicians to signal their activism without incurring major costs.

Previous studies show that terrorism increases voters' turnout and the support for rightwing parties (Balcells and Torrats-Espinosa 2018; Berrebi and Klor 2008; Getmansky and Zeitzoff 2014). In addition, we know that terrorism and migration are often (inappropriately) linked, and despite a lack of empirical support for a direct effect of immigration on terrorism (Bove and Böhmelt 2016; Dreher et al. 2017; McAlexander 2019), terrorism abroad can lead to negative attitudes toward immigrants at home (Böhmelt et al.2019; Finseraas et al.2011; Legewie 2013; Schüller 2016). Yet, little is known about the impact of proximity to terrorism on the formation of public policies. We thus depart from earlier works in that we demonstrate that terrorism abroad affects the actual implementation of more restrictive immigration policies at home.

In the following, we build on agenda-setting (Cohen et al. 1972; Kingdon 2003) and present a parsimonious analytical framework to understand how terrorist violence in neighboring countries may make security concerns prominent and push them to the core of public attention. We then use spatial econometrics to demonstrate how countries affected by terrorism in their immediate proximity are likely to move toward more restrictive regulations and control mechanisms. 


\section{Agenda, Solutions, and Political Will}

We examine whether terrorist attacks exert an influence on migration policy beyond the borders of targeted countries, using a framework based on agenda setting (Cohen et al. 1972; Kingdon 2003). First, a terrorist attack focuses the attention of a broader audience and thus shapes the political agenda. We argue that the attention news media dedicate to a particular attack depends on geographic proximity. Second, once terrorism receives sufficient attention and finds its place on the political agenda, potential policy solutions are debated. Although migration is not directly linked to terrorism, this policy domain has been securitized in the wake of terrorist attacks. We thus contend that migration policy provides policymakers with a suitable field of action in the aftermath of terrorist attacks. Third, politicians can resort to migration policy to show resolve to their voters. We argue that they are motivated by pressure from public opinion, political opportunism, and anticipation of other countries' choices. Together, these three processes lead to more restrictive migration policy in countries in proximity to terrorist attacks abroad.

\section{Terrorism as Focusing Events}

Terrorist attacks are "focusing events" (Kingdon 2003: 94-100), which tend to quickly inform the top priorities of the political agenda (Huysmans 2006; Worrall 1999). Emblematic terrorist attacks like 9/11 or the 2015 Bataclan attacks are examples of such focusing events, which usually receive global media attention and are important drivers of public opinion (Lippmann 2017; McCombs 2018; McCombs and Shaw 1972). However, not all terrorist attacks are as large and shocking, and not all of them make it into the global news. For the average terrorist incident in other countries, media attention depends, in part, on geographic proximity (i.e., the physical distance of an individual to the place where an event occurred). Proximity to a terrorist incident heightens the perception of threat (Stamps 2011) and affects the degree to which an event is covered by the media as well as the type of frame journalists apply 
(Shoemaker et al. 2007). This has been found for news reporting in the US (Nossek and Berkowitz 2006), Sweden (Westerståhl and Johansson 1994), and other states (Aalberg et al. 2013; Koopmans and Vliegenthart 2011). As Kwon et al. (2017: 875) emphasize, “when thinking about a terrorist event that occurred far away [...], one would likely think of social and political reasons that address why it happened, but closer to the place or date of the event, one may likely focus on specific issues such as how to locate missing families, find the perpetrators, steps for reassuring the affected community and other logistical concerns." Thus, it is crucial whether acts of terrorism are distant or nearby for understanding audiences' reactions of fear and their attitudes toward external security threats (Avdan and Webb 2019). ${ }^{1}$

Yet, although terrorism can receive broad coverage and attention in a targeted country and its proximity, prompting its inclusion in the list of pressing items of the public agenda, this does not automatically translate into policy action (Anderson et al. 2017; Boswell et al. 2019). Policymakers process issues sequentially (Walgrave and Dejaeghere 2017) and - in addition to high issue salience and prominent media coverage - sufficient public attention, relevant policy solutions to address the problem, and political will to implement those policies are needed.

\section{Policy Solutions in Response to Terrorism}

What policy solutions are available to prevent terrorist attacks? Policy entrepreneurs continuously discuss options (Kingdon 2003: 116) and an external shock like terrorism can disrupt multiple policy areas, thus creating a window of opportunity for a wide array of policy innovations (May et al. 2009). Changes in security policy are a common response, given that terrorism may be addressed with more effective intelligence strategies (Bonfanti 2016) or guarding critical infrastructures (Spaaij and Hamm 2015; UNICRI 2014). These policy options may be classified as pertaining to the security domain. Some of them conflict with citizens' individual freedom (Epifanio 2016), though, which implies that they are only 
supported by the broader public if a security threat is sufficiently developed and perceived as such (Davis and Silver 2004). Governments could even decide to fight against terrorist organizations abroad if they identify the threat of terrorism as originating in a foreign "safe haven" (Hetherington and Suhay 2011; Merolla and Zechmeister 2009). Alternatively, policy entrepreneurs may focus on preventing "homegrown" terrorism through policies that revolve around the ideas of countering extremist narratives and psychological de-radicalization (Greenberg 2016; Selim 2016).

In addition to classical security policies and targeted prevention strategies, migration legislation is increasingly identified as a potential policy domain to address terrorist threats due to the assumed (albeit oftentimes wrong) association of terrorism and migration. Migration has become a policy priority in its own right over the course of the past decades (Geddes and Scholten 2003). The threat of terrorism has given migration policy an additional spin, namely, to counter terrorism. In fact, migration is now framed as part of security policy. The former Spanish Minister of Foreign Affairs, Josep Piqué, declared once that, "the fight against illegal immigration is also the reinforcement of the fight against terrorism" (Rudolph 2003: 616). Even the UN Security Council recommends effective border security and controls on issuance of identity papers and travel documents in Resolution 1373 to prevent the movement of terrorists. In the context of the recent wave of terrorism, migration has thus been securitized and directly attached to terrorism (Avdan 2014b; Huysmans 2006), making migration policy a popular tool to address terrorism and the assumed nexus between migration and security the foundation for policymaking (Tirman 2004). ${ }^{2}$ While conflicting with the goals of a free market economy, border controls, tightened asylum rights, and more restrictive immigration practices have become readily available policy solutions to deal with terrorism (Avdan 2014b).

Clearly, not all the mentioned policy solutions are relevant for all countries at all times (Epifanio 2016). Only few states have the capability to militarily intervene in another country 
to fight terrorism and not all face threats of extremist radicalization in their own territory. The suitability of a specific policy solution thus depends on context. For migration policy, we contend that proximity to the targeted country is a relevant contextual condition. If a neighbor chooses to restrict their migration policy, others may be pressed to do the same (Neumayer et al. 2014), given that future terrorists could seek to attack the weakest target in the vicinity (Sandler and Lapan 1988). To avoid becoming the weakest target, politicians may anticipate this dynamic and restrict their migration policy before their neighbors do. This mechanism anticipating neighbors' restrictions to immigration - makes policy entrepreneurs from within government present restrictive migration policy as a particularly relevant and pressing solution in states that are close to targeted countries.

\section{Politicians' Policy Choice in Response to Public Opinion}

When the public is alerted to terrorism, politicians in democratic countries are hard pressed to act (Kydd and Walter 2006). Domestic audiences care about security threats, and the citizenry can remove democratic leaders relatively easily if they are dissatisfied with their performance (Mesquita et al. 2004). ${ }^{3}$ Politicians thus take into account the costs and benefits that arise from affecting their voter base directly. Earlier research shows that citizens are willing to trade their individual freedom for more security if threats are extraordinary (Davis and Silver 2004). As a consequence, politicians in directly affected countries with a proven presence of terrorists in their territory are the most willing to tighten counterterrorist regulations (Neumayer et al. 2014). The state of emergency declared in France after the Bataclan attacks illustrates this (The Independent 2017). However, while politicians are generally called to action, they need to read the national mood and choose policies that do not come at the expenses of their own constituencies.

Migration policy is an ideal instrument in this regard as mainly foreign-born individuals

suffer the direct consequences from more restrictiveness (Borjas 2014). ${ }^{4}$ With migration 
policy, politicians show their resolve to act against terrorism without the risk of aggravating too many voters. As Dreher et al. (2017) put it, "it is easier to restrict the rights of foreigners in order to increase the (perceived) security of a country's natives than to restrict the rights of these natives (i.e., voters) themselves." The migration topic thus provides politicians with an opportunity to show resolve. By asserting a stronger control of territorial boundaries through more restrictive immigration laws, they affirm their "role as providers of protection and security" (Bigo 2002: 65).

Evidently, politicians' motivations to restrict migration policy can be diverse: pressure from public opinion, political opportunism, and anticipating other countries' responses are the key drivers here. First, research on the impact of terrorism on public opinion tells us that citizens view foreigners more negatively in the wake of terrorism (Boomgaarden and de Vreese 2007; Finseraas and Listhaug 2013; Goodwin et al. 2017; Hitlan et al. 2007; Kalkan et al. 2009; Legewie 2013; Schüller 2016; Van de Vyver et al. 2016). Also, increasing concern about migration is not contained to targeted countries, but can diffuse across borders (Böhmelt et al.2019; Nussio et al. 2019). In line with these changes in opinion, migrants are often blamed for terrorist attacks by the general public. This is likely the result of an association of terrorism and migration in news reporting (Das et al. 2009), and the related securitization of migration (Huysmans 2006; Woods and Arthur 2017). Especially Muslims are often singled out as a security threat (Haner et al. 2019). ${ }^{5}$ And there is evidence that terror attacks make citizens generally more supportive of restrictive immigration policy (Finseraas et al. 2011). From the perspective of public opinion, migration is thus an attractive field of engagement for politicians in times of uncertainty. Politicians of different colors may want to signal to their citizens that they take swift and visible actions.

Second, politicians may see terrorism as a window of opportunity to promote their own political platforms and serve a more nationalistically minded voter clientele. ${ }^{6}$ They may even have an active interest in promoting the view of a terrorism-migration nexus, as it provides 
them with an opportunity to restrict migration policy under the pretext of generating more security (see Haider-Markel et al. 2006). ${ }^{7}$

Third, politicians may want to anticipate the policy changes in other countries. If proximate countries restrict their migration policy and there is widespread belief that terrorists pick the weakest target in the vicinity, not restricting migration policy may be seen as leaving the door open for terrorists (Neumayer et al. 2014). In hindsight, politicians would thus have to bear the responsibility for not restricting migration policy earlier if an attack was to occur. In anticipation of this dynamic, there are clear incentives to restrict migration policy if an attack in a country's vicinity elevates the salience of this topic, even if policymakers do not believe in its effectiveness.

In sum, terrorist attacks focus the public's attention to the problem of terrorism, especially in proximate states where the news value of a violent attack is higher than in more distant locations. Policy entrepreneurs continuously discuss a series of policy solutions to address terrorism, and migration policy is a seemingly intuitive domain of action given the securitization of migration and the anticipation of being the weakest target in the vicinity. In this context, politicians choose policy options to deal with terrorism and increase their voter support in response to public opinion and political opportunism, as well as in anticipation of other countries' policies. Therefore, restricting migration policy likely is a preferred course of action in proximate countries. In accordance with this theoretical reasoning, we expect that terrorist attacks in nearby countries lead to a more restrictive migration policy at home.

\section{Research Design}

For our empirical analysis, we created a country-year data set comprising 33 OECD countries between 1980 and $2010 .^{8}$ The following describes how we created the data set, focusing on the outcome variable, the explanatory items, and the controls, and we specify the estimation approach. First, our dependent variable is based on the Determinants of International 
Migration (DEMIG) Policy Database (Haas et al. 2014). ${ }^{9}$ These data track major and minor policy changes in migration laws for a large number of countries in the post-World War II period. The key advantage of the DEMIG data is that it has a larger spatial and temporal scope than most other data sets on migration policies. ${ }^{10}$ The content of each policy measure is coded via four variables - two items on the issue (policy area and tool) and two coding the group targeted (migrant category and geographic origin). Particularly relevant for our research, the policy area consists of four codes: border and land control, legal entry and stay, exit, and integration policies. ${ }^{11}$ Whereas the first three categories are more obvious domains of action that policymakers may seek to manipulate in the wake of terrorism abroad, we also expect integration policies to be targeted. As Haas et al. $(2014,5)$ emphasize, "post-entry rights may play a role (as deterring, attracting, or retaining factor) in the migration decision of potential future migrants as well as migrants already in the country [...] Restrictive access to social benefits is often used to deter future asylum and other 'undesired' migrants." Hence, creating unattractive conditions is another course of action to curb the inflow of immigrants in presence of terrorism abroad.

The DEMIG data code for each policy whether it "represents a change towards more or less restrictiveness of the existing legal framework. It also mentions cases in which policy measures do not introduce any change in restrictiveness or when it cannot be assessed." According to the codebook, more restrictive policies intend to "restrict [more] the rights of a migrant group, herewith making the existing legal framework more restrictive than before.” In this context, "restrictiveness" is based on five coding criteria: (1) quantity, i.e., whether the measure restricts the pool of immigrants gaining migration rights; (2) composition, i.e., whether the measure raises/specifies the eligibility criteria for entry and stay of a particular migrant group; (3) procedure, i.e., whether the measure makes specific procedures more complicated for the target group; (4) choice, i.e., whether the measure restricts the choices available to immigrants; and (5) control, i.e., whether the measure increases the level of 
control on migrants at the border or within the territory. For the purpose of our analysis, we opt for a dichotomous coding that receives the value of 1 if at least one, more restrictive immigration policy measure has been implemented in a given country-year ( 0 otherwise). The coding of migration policies' restrictiveness is difficult due to complex coding criteria. Aggregating and recoding the implementation of more restrictive migration policy into a binary variable has the advantage to mitigate this issue by reducing the risk of coding error. That said, the appendix considers alternative specifications.

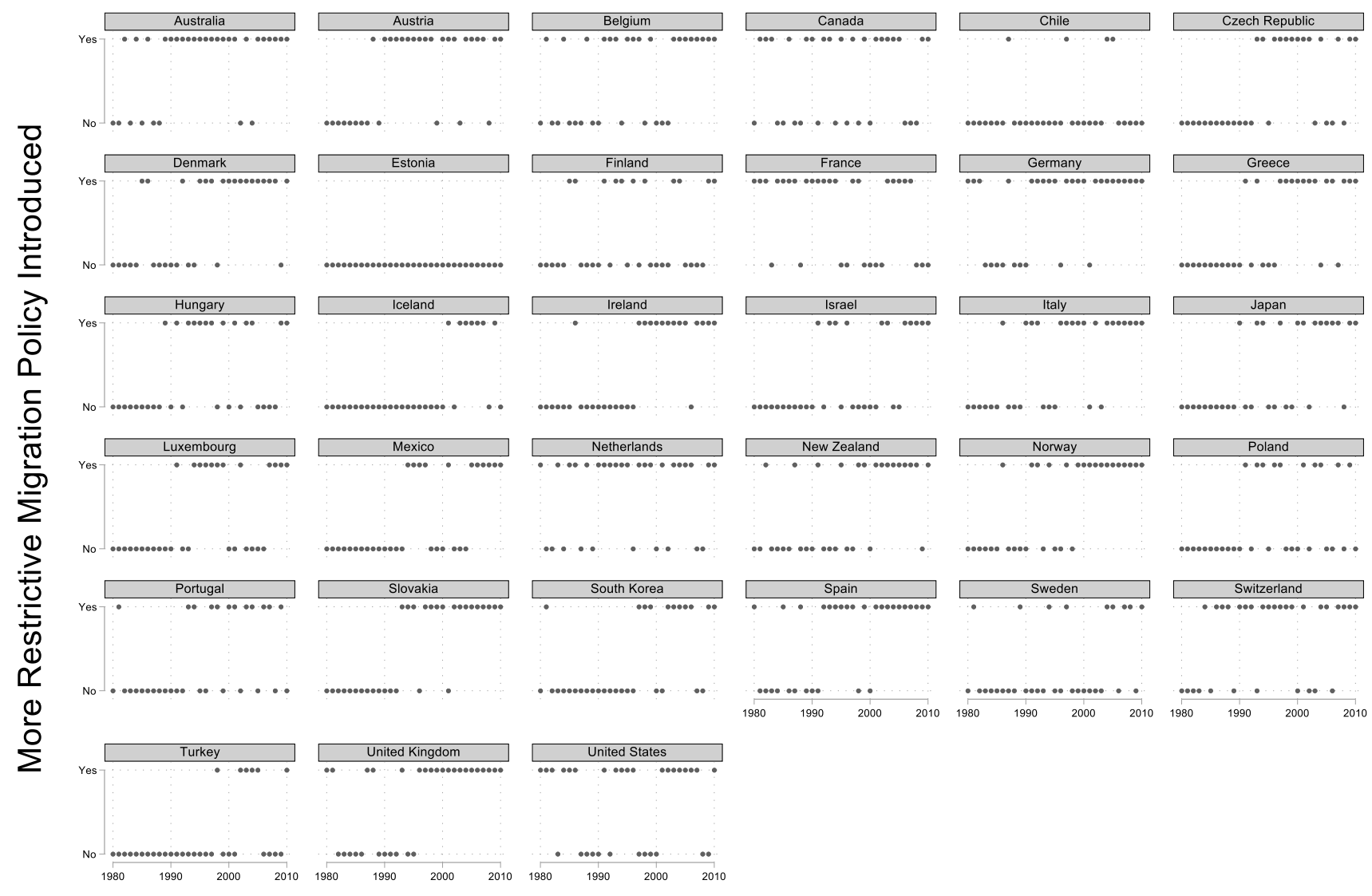

Figure 1. Implementation Migration Policies

Figure 1 plots our dependent variable for the 33 OECD countries included in the analysis. There is a significant amount of variation in the odds of observing the introduction of at least one more restrictive immigration policy every year - both across countries as well as within each state over time. As the outcome variable is binary, we use logistic regression models. To address temporal dependencies in the analyses, we calculate cubic polynomials based on the time elapsed (in years) since the last more restrictive policy has been implemented (Carter and 
Signorino 2010). Intra-group, i.e., country-specific path dependencies and correlations are captured by clustering the standard errors at this level. As coefficients in non-linear models cannot be interpreted directly, we report marginal effects and first differences for the changes in the probabilities of a policy-restriction change.

For our main explanatory variable, we rely on the GTD's definition of terrorism, which is "the premeditated use or threat to use violence by individuals or sub-national groups against non-combatants in order to obtain a political or social objective through the intimidation of a large audience beyond that of the immediate victims" (Enders et al. 2011: 321). The GTD codes the number of terrorist incidents and their nature for each country-year. We seek to model how the probability of a more restrictive migration law being introduced at home is influenced by other countries' terrorism. The item capturing this mechanism is a spatial variable, $\boldsymbol{W} x_{t}:$ Terrorism, which is the product of a binary item receiving a value of 1 if at least one terrorist attack occurred in a given country-year abroad ( 0 otherwise) $)^{12}$ and a nonrow-standardized weighting matrix $(\boldsymbol{W})$. The values $\left(w_{i, j}\right)$ in $\boldsymbol{W}$ measure the relative connectivity of the destination country $i$ with $j$ as the state of origin (with $w_{i, i}=0$ ), as defined by the Direct Contiguity Data (Stinnett et al. 2002). We expect $\boldsymbol{W} x_{t}$ :Terrorism to be positively signed and statistically significant.

When estimating any spatial effect, we must control for "exogenous-external conditions or common shocks and spatially correlated unit level factors" (Franzese and Hays 2007: 142) to address concerns about common exposure, i.e., what might appear to be a diffusion effect is actually driven by unit-level features that spatially cluster, common trends, and exogenous shocks. Following Franzese and Hays (2007; 2008), we therefore incorporate temporal controls (described above) and, in some of our models, fixed effects for countries and years. In combination with several control variables that we describe below, we can credibly ensure that the proclaimed diffusion effect is indeed genuine (Buhaug and Gleditsch 2008; Plümper and Neumayer 2010). ${ }^{13}$ 
For the control variables, first, there is a state's level of democracy based on the combined polity score from the Polity IV project. This 21 -point scale ranges from -10 to +10 , with higher values standing for more democratic forms of government. Previous research points to a strong relationship between democracy and immigration laws (Breunig et al. 2012). Second, we control for GDP per capita and population size, which are both logtransformed and taken from the World Bank Development Indicators. Both items correlate with migration flows (e.g., Helbling and Leblang 2019) and, thus, are likely also related to migration policies. Third, the number of immigrants (log-transformed), summed across all sending countries, controls for foreign-born populations' self-selection into focal countries, as more restrictive immigration policies can be implemented to control the borders and limit the number of new arrivals (Breunig et al. 2012; Helbling and Leblang 2019). Fourth, we control for a country's level of integration in the global economy as well as the world's political network using the globalization index from Dreher (2006). More open states may have more open migration-policy regimes. Finally, to address other temporal dynamics besides those picked up by the temporal controls and the year fixed effects discussed above, we consider two dichotomous variables: one for the Cold War period, which receives a value of 1 until the year 1991 (0 afterwards), and one for the post-9/11 period. Terrorism, and migration laws, may have fundamentally changed after those key events in the international system (Sandler 2014). In the appendix, we summarize the descriptive statistics of all variables used.

\section{Empirical Findings}

We summarize our main models in Table 1. All estimations presented there are based on logistic regression models. In Model 1, we only include the temporal controls next to our core explanatory item. Model 2 adds the substantive controls introduced in the previous section. In Model 3, we omit the two binary items Cold War and Post 9/11 as we include the set of year fixed effects instead. Finally, Model 4 considers country fixed effects in order to control for 
unit-level, time-invariant influences instead of the substantive predictors. Comparing regression results with increasing numbers of controls in this way - that is, comparing uncontrolled results, results with crude controls, and results with fixed effects - offers interesting insights. In fact, Models 2-3 outperform the other two estimations according to the model-fit statistics. Most importantly, the Area-under-Curve (AUC) statistics suggest high (in-sample) predictive power for either model with scores of 0.780 (Model 2) and 0.814 (Model 3), respectively. Yet, despite differences in model fit, the variables' effects are rather consistent across the models.

Table 1. Migration Policies at Home and Terrorism Abroad

\begin{tabular}{|c|c|c|c|c|}
\hline & Model 1 & Model 2 & Model 3 & Model 4 \\
\hline$W x_{t}:$ Terrorism & $\begin{array}{l}0.130^{* * *} \\
(0.033)\end{array}$ & $\begin{array}{c}0.070^{*} \\
(0.036)\end{array}$ & $\begin{array}{c}0.086^{*} \\
(0.044)\end{array}$ & $\begin{array}{c}0.148^{* *} \\
(0.060)\end{array}$ \\
\hline Migration (ln) & & $\begin{array}{c}0.196^{* *} \\
(0.095)\end{array}$ & $\begin{array}{c}0.220^{* *} \\
(0.101)\end{array}$ & \\
\hline Population (ln) & & $\begin{array}{c}0.011 \\
(0.083)\end{array}$ & $\begin{array}{r}-0.014 \\
(0.091)\end{array}$ & \\
\hline GDP per capita $(\ln )$ & & $\begin{array}{c}0.226 \\
(0.161)\end{array}$ & $\begin{array}{c}0.182 \\
(0.173)\end{array}$ & \\
\hline Democracy & & $\begin{array}{c}0.052 \\
(0.047)\end{array}$ & $\begin{array}{c}0.054 \\
(0.052)\end{array}$ & \\
\hline Cold War & & $\begin{array}{l}-0.926^{* * *} \\
(0.210)\end{array}$ & & \\
\hline Post 9/11 & & $\begin{array}{l}0.488^{* * *} \\
(0.187)\end{array}$ & & \\
\hline Globalization & & $\begin{array}{c}0.010 \\
(0.015)\end{array}$ & $\begin{array}{c}0.007 \\
(0.016)\end{array}$ & \\
\hline Time & $\begin{array}{l}-0.663^{* * *} \\
(0.091)\end{array}$ & $\begin{array}{l}-0.382^{* * * *} \\
(0.122)\end{array}$ & $\begin{array}{l}-0.413^{* * *} \\
(0.125)\end{array}$ & $\begin{array}{l}-0.572^{* * *} \\
(0.102)\end{array}$ \\
\hline Time $^{2}$ & $\begin{array}{l}0.065^{* * *} \\
(0.016)\end{array}$ & $\begin{array}{c}0.049^{* * *} \\
(0.022)\end{array}$ & $\begin{array}{c}0.046^{* *} \\
(0.021)\end{array}$ & $\begin{array}{l}0.054^{* * *} \\
(0.017)\end{array}$ \\
\hline Time $^{3}$ & $\begin{array}{l}-0.002^{* * * *} \\
(0.001)\end{array}$ & $\begin{array}{l}-0.002^{*} \\
(0.001)\end{array}$ & $\begin{array}{l}-0.002^{*} \\
(0.001)\end{array}$ & $\begin{array}{r}-0.001^{* *} \\
(0.001)\end{array}$ \\
\hline Constant & $\begin{array}{l}0.226 \\
(0.143)\end{array}$ & $\begin{array}{l}-5.966^{* * * *} \\
(2.202)\end{array}$ & $\begin{array}{l}-6.741^{* * * *} \\
(2.225)\end{array}$ & $\begin{array}{r}-0.602^{* * * *} \\
(0.107)\end{array}$ \\
\hline Obs. & 1,023 & 961 & 961 & 992 \\
\hline Country Fixed Effects & No & No & No & Yes \\
\hline Year Fixed Effects & No & No & Yes & No \\
\hline Log Pseudolikelihood & -620.618 & -538.587 & -504.800 & -595.919 \\
\hline Prob $>\chi^{2}$ & 0.000 & 0.000 & 0.000 & 0.000 \\
\hline AUC & 0.725 & 0.780 & 0.814 & 0.739 \\
\hline
\end{tabular}

Note: Table entries are coefficients; standard errors clustered on country in parentheses. $* \mathrm{p}<0.10,{ }^{* *} \mathrm{p}<0.05, * * * \mathrm{p}<0.01$. 
Focusing on our main variable of interest, $\boldsymbol{W} x_{t}$ :Terrorism is positively signed and statistically significant. Specification changes as done in Table 1 or considering other model alterations as in the appendix do not alter the results. Figure 2 depicts the substantive impact of $\boldsymbol{W} x_{t}$ :Terrorism as we plot how the probability of implementing at least one stricter migration policy changes given the different values of the spatial variable. When moving from the minimum ( 0 terrorist attacks in all neighboring states) toward the maximum (11 terrorist attacks in all neighboring states) of $\boldsymbol{W} x_{t}:$ Terrorism, the chance to see a more restrictive migration law being implemented increases by about 35 percentage points. Thus, our theoretical expectations are confirmed in that domestic migration laws are driven by terrorist attacks abroad.

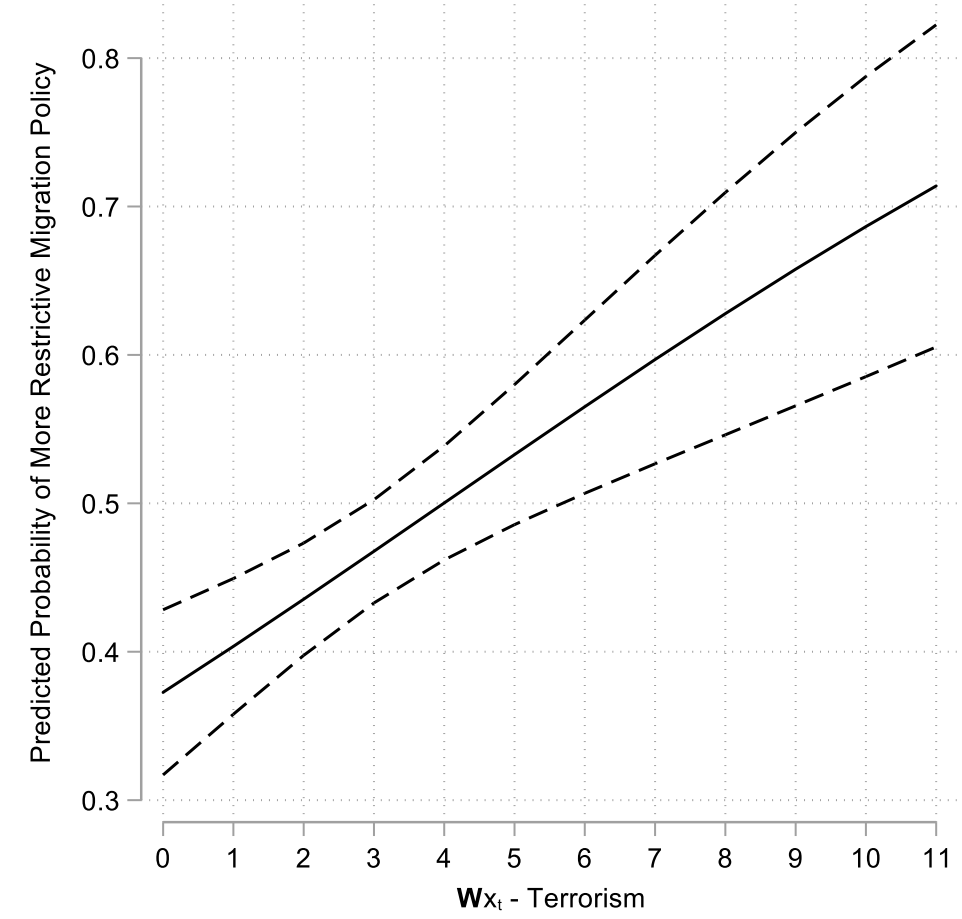

Figure 2. Migration Policy Restrictions: The Impact of $\mathbf{W} x \mathrm{t}$ : Terrorism

Note: Graph shows predicted probabilities of Migration Policy=1, while holding all other covariates constant at their means; dashed lines signify 95 percent confidence intervals; figure is based on Model 1, but substantively similar for the other estimations in Table 1.

In terms of the control variables, consistently significant patterns are shown for three items. First, Migration $(\ln )$ is positively signed. In our view, reverse causality is therefore less of an issue as migrants are usually attracted by destination countries with less restrictive 
policies (Breunig et al. 2012). Instead, it seems more plausible that a larger number of migrants in a state increases the likelihood of more restrictive policies in order to regulate migration influx. In Model 2, increasing Migration $(\ln )$ from its minimum to its maximum is associated with a rise in the probability to see at least one more restrictive policy being implemented of about 40 percentage points. Second, we considered temporal controls for the Cold War and the post-9/11 periods. On one hand, more restrictive policies were significantly less likely during the Cold War by about 22 percentage points, all else equal. On the other hand, the probability to see more restrictive policies after the 9/11-terrorist attacks is higher by about 12 percentage points compared to the years before 2001. From that perspective, the substantive effect of $\boldsymbol{W} x_{t}$ :Terrorism is the same order of magnitude of other, arguably important, determinants of migration policies.

\section{Conclusion}

The determinants of immigration laws are of major interest today. The rise in migration inflows in the last few decades as well as the recent European "refugee and migration crisis" sparked an intense debate among policymakers, the public, and scholars on how to best address transnational population movements. We develop an argument proposing that governments are more likely to implement more restrictive policies in light of terrorism in other countries. We claim that terrorism in neighboring states affects the salience of security threats and the attention paid by the domestic audience to security concerns. A terrorist attack abroad also shapes the type of policy solution for addressing it and the political will to implement changes. Policymakers, in an attempt to signal their citizens that they take control over security concerns, will seek to please the domestic audience with feasible policies.

A key assumption underlying our research is that terrorism is closely linked to migration in the perception of policymakers and the general public. Although there is little evidence to support an objective link, the perception of an association is, in fact, pervasive among the 
general European public. Political leaders, including in countries that have not been targeted by terrorists, also superficially relate terrorism to immigration and advocate for stricter migration policies based on the perceived risk. As a variant of this perception of a migrationterrorism nexus, we focus on how terrorism abroad shapes migration policies at home. We demonstrate that terrorism in neighboring countries does indeed influence the likelihood of more restrictive migration laws being implemented in the focal country. This result adds significantly to contemporary debates about the political consequences of terrorism, diffusion processes, and the security implications of population movements, since we suggest that there are significant harmful effects that go well beyond the affected societies.

Several avenues for future research might emerge out of our work. An interesting question is whether different markers of proximity, such as social or cultural distance to the targeted region, as well as the nature of the victims and perpetrators could amplify some effects of terrorism. The scope conditions of our argument and how exactly counterterrorism policies and migration restrictions relate to each other is also left unexplored. A potential agenda for future research in this area is discussed in detail in the appendix.

\section{References}

Aalberg, T. et al. (2013) 'International TV News, Foreign Affairs Interest and Public Knowledge', Journalism Studies 14(3): 387-406.

Alonso, S. and Fonseca, S. C. da (2012) 'Immigration, left and right', Party Politics 18(6): 865-884.

Anderson, B., Böhmelt, T. and Ward, H. (2017) 'Public opinion and environmental policy output: a cross-national analysis of energy policies in Europe', Environmental Research Letters 12(11): 114011.

Avdan, N. (2014a) 'Controlling Access to Territory: Economic Interdependence, Transnational Terrorism, and Visa Policies', Journal of Conflict Resolution 58(4): 592-624.

Avdan, N. (2014b) 'Do asylum recognition rates in Europe respond to transnational terrorism? The migration-security nexus revisited', European Union Politics 15(4): 445-471.

Avdan, N. and Webb, C. (2019) 'Not in My Back Yard: Public Perceptions and Terrorism', Political Research Quarterly 72(1): 90-103. 
Balcells, L. and Torrats-Espinosa, G. (2018) 'Using a natural experiment to estimate the electoral consequences of terrorist attacks', Proceedings of the National Academy of Sciences 115(42): 10624-10629.

Bandyopadhyay, S. and Sandler, T. (2014) 'Immigration policy and counterterrorism', Journal of Public Economics 110: 112-123.

Beine, M. et al. (2016) 'Comparing Immigration Policies: An Overview from the IMPALA Database', International Migration Review 50(4): 827-863.

Berrebi, C. and Klor, E. F. (2008) 'Are voters sensitive to terrorism? Direct evidence from the israeli electorate’, American Political Science Review 102(3): 279-301.

Bigo, D. (2002) 'Security and Immigration: Toward a Critique of the Governmentality of Unease', Alternatives 27: 63-92.

Böhmelt, T., Bove, V. and Nussio, E. (2019) 'Can Terrorism Abroad Influence Migration Attitudes at Home?', American Journal of Political Science.

Bonfanti, M. E. (2016) 'Collecting and Sharing Intelligence on Foreign Fighters', in A. de Guttry, F. Capone, and C. Paulussen (eds). Foreign Fighters under International Law and Beyond. Den Haag: T.M.C. Asser Press, pp. 333-353.

Boomgaarden, H. G. . and de Vreese, C. H. (2007) 'Dramatic Real-world Events and Public Opinion Dynamics: Media Coverage and its Impact on Public Reactions to an Assassination', International Journal of Public Opinion Research 19(3): 354-366.

Borjas, G. J. (2014) Immigration Economics, Boston: Harvard University Press.

Boswell, J. et al. (2019) 'State of the field: What can political ethnography tell us about anti-politics and democratic disaffection?', European Journal of Political Research 58(1): 56-71.

Bove, V. and Böhmelt, T. (2016) 'Does Immigration Induce Terrorism?', The Journal of Politics 78(2): 572-588.

Bove, V. and Elia, L. (2017) 'Migration, Diversity, and Economic Growth', World Development 89: 227-239.

Breunig, C., Cao, X. and Luedtke, A. (2012) 'Global Migration and Political Regime Type: A Democratic Disadvantage', British Journal of Political Science 42(4): 825-854.

Buhaug, H. and Gleditsch, K. S. (2008) 'Contagion or Confusion? Why Conflicts Cluster in Space', International Studies Quarterly 52(2): 215-233.

Bump, P. (2019) 'How Trump talks about attacks targeting Muslims vs. attacks by Muslims', Washington Post 18 May, available at https://www.washingtonpost.com/politics/2019/03/18/how-trump-talks-about-attackstargeting-muslims-vs-attacks-by-muslims/.

Carter, D. B. and Signorino, C. S. (2010) 'Back to the Future: Modeling Time Dependence in Binary Data’, Political Analysis 18(3): 271-292.

Cerna, L. (2016) 'The crisis as an opportunity for change? High-skilled immigration policies across Europe', Journal of Ethnic and Migration Studies 42(10): 1610-1630.

Choi, S.-W. (2018) 'Does Restrictive Immigration Policy Reduce Terrorism in Western Democracies?', Perspectives on Terrorism 12(4): 14-25. 
Cohen, M. D., March, J. G. and Olsen, J. P. (1972) 'A Garbage Can Model of Organizational Choice', Administrative Science Quarterly 17(1): 1-25.

d'Appollonia, A. C. and Reich, S. (eds) (2008) Immigration, Integration, and Security: America and Europe in Comparative Perspective, Pittsburgh: University of Pittsburgh Press.

Dancygier, R. M. (2010) Immigration and Conflict in Europe, New York: Cambridge University Press.

Das, E., Bushman, B. J., Bezemer, M. D., Kerkhof, P. and Vermeulen, I. E. (2009) 'How terrorism news reports increase prejudice against outgroups', Journal of Experimental Social Psychology 45(3): 453-459.

Davis, D. W. and Silver, B. D. (2004) 'Civil Liberties vs. Security: Public Opinion in the Context of the Terrorist Attacks on America', American Journal of Political Science 48(1): 28-46.

Downs, A. (1957) An economic theory of democracy, New York: Harper.

Dreher, A., Gassebner, M. and Schaudt, P. (2017) The Effect of Migration on Terror - Made at Home or Imported from Abroad?, Rochester, NY: Social Science Research Network, available at https://papers.ssrn.com/abstract=2977480 (accessed January 2019).

Enders, W., Sandler, T. and Gaibulloev, K. (2011) 'Domestic versus transnational terrorism: Data, decomposition, and dynamics', Journal of Peace Research 48(3): 319-337.

Epifanio, M. (2016) 'The Politics of Targeted and Untargeted Counterterrorist Regulations', Terrorism and Political Violence 28(4): 713-734.

Epifanio, M. and Plümper, T. (2018) 'European integration and the race to the top in counterterrorist regulations', Journal of European Public Policy 25(5): 787-799.

Fahmy, S. (2010) 'Contrasting visual frames of our times: A framing analysis of English- and Arabiclanguage press coverage of war and terrorism', International Communication Gazette 72(8): 695-717.

Farman, D. and Nussio, E. (2018) Views on Islam in Times of Terrorism, Zurich: ETH Zurich.

Finseraas, H., Jakobsson, N. and Kotsadam, A. (2011) 'Did the Murder of Theo van Gogh Change Europeans’ Immigration Policy Preferences?’, Kyklos 64(3): 396-409.

Finseraas, H. and Listhaug, O. (2013) 'It can happen here: the impact of the Mumbai terror attacks on public opinion in Western Europe', Public Choice 156(1-2): 213-228.

Franzese, R. J. and Hays, J. C. (2007) 'Spatial Econometric Models of Cross-Sectional Interdependence in Political Science Panel and Time-Series-Cross-Section Data', Political Analysis 15(2): 140-164.

Franzese, R. J. and Hays, J. C. (2008) 'Interdependence in Comparative Politics: Substance, Theory, Empirics, Substance', Comparative Political Studies 41(4-5): 742-780.

Geddes, A. and Scholten, P. (2003) The Politics of Migration and Immigration in Europe, Thousand Oaks: SAGE.

Getmansky, A. and Zeitzoff, T. (2014) 'Terrorism and voting: The effect of rocket threat on voting in israeli elections', American Political Science Review 108(3): 588-604. 
Gilardi, F. (2010) 'Who Learns from What in Policy Diffusion Processes?', American Journal of Political Science 54(3): 650-666.

Gillum, R. M. (2018) Muslims in a Post-9/11 America: A Survey of Attitudes and Beliefs and Their Implications for U.S. National Security Policy, Ann Arbor: University of Michigan Press.

Givens, T. and Luedtke, A. (2005) 'European Immigration Policies in Comparative Perspective: Issue Salience, Partisanship and Immigrant Rights', Comparative European Politics 3(1): 1-22.

Goodwin, R., Kaniasty, K., Sun, S. and Ben-Ezra, M. (2017) 'Psychological distress and prejudice following terror attacks in France', Journal of Psychiatric Research 91: 111-115.

Greenberg, K. J. (2016) 'Counter-Radicalization via the Internet', The ANNALS of the American Academy of Political and Social Science 668(1): 165-179.

Guiso, L., Sapienza, P. and Zingales, L. (2009) 'Cultural Biases in Economic Exchange?', The Quarterly Journal of Economics 124(3): 1095-1131.

Haas, H. de, Natter, K. and Vezzoli, S. (2014) 'Compiling and coding migration policies: Insights from the DEMIG POLICY database', IMI Working Paper Series 87, available at https://www.imi-n.org/publications/wp-87-14 (accessed January 2019).

Haider-Markel, D. P., Joslyn, M. R. and Al-Baghal, M. T. (2006) 'Can We Frame the Terrorist Threat? Issue Frames, the Perception of Threat, and Opinions on Counterterrorism Policies', Terrorism and Political Violence 18(4): 545-559.

Haner, M., Sloan, M. M., Cullen, F. T., Kulig, T. C. and Lero Jonson, C. (2019) 'Public Concern about Terrorism: Fear, Worry, and Support for Anti-Muslim Policies', Socius 5.

Helbling, M., Bjerre, L., Römer, F. and Zobel, M. (2017) 'Measuring Immigration Policies: the IMPIC database', European Political Science 16(1): 79-98.

Helbling, M. and Kalkum, D. (2018) 'Migration policy trends in OECD countries', Journal of European Public Policy 25(12): 1779-1797.

Helbling, M. and Leblang, D. (2019) 'Controlling immigration? How regulations affect migration flows', European Journal of Political Research 58(1): 248-269.

Helbling, M. and Meierrieks, D. (2018) Seminar: Transnational Terrorism and Restrictive Immigration Policies - Migration Policy Centre - MPC, University of Bamberg, available at $\mathrm{http} / /$ www.migrationpolicycentre.eu/event/seminar-transnational-terrorism-and-restrictiveimmigration-policies/ (accessed October 2019).

Helbling, M. and Michalowski, I. (2017) 'A New Agenda for Immigration and Citizenship Policy Research', Comparative Political Studies 50(1): 3-13.

Hetherington, M. J. and Suhay, E. (2011) 'Authoritarianism, Threat, and Americans' Support for the War on Terror', American Journal of Political Science 55(3): 546-560.

Hitlan, R. T., Carrillo, K., Zárate, M. A. and Aikman, S. N. (2007) 'Attitudes toward immigrant groups and the September 11 terrorist attacks', Peace and Conflict: Journal of Peace Psychology 13(2): 135-152.

Howard, M. M. (2009) The Politics of Citizenship in Europe, Cambridge: Cambridge University Press.

Huysmans, J. (2006) The politics of insecurity: fear, migration and asylum in the EU, Abingdon and New York: Routledge. 
Joppke, C. (2017) 'Civic integration in Western Europe: three debates', West European Politics 40(6): $1153-1176$

Kalkan, K. O., Layman, G. C. and Uslaner, E. M. (2009) “"Bands of Others”? Attitudes toward Muslims in Contemporary American Society', The Journal of Politics 71(3): 847-862.

Kingdon, J. W. (2003) Agendas, Alternatives and Public Policies, 2nd Ed., New York: Longman Higher Education.

Koopmans, R., Michalowski, I. and Waibel, S. (2012) 'Citizenship Rights for Immigrants: National Political Processes and Cross-National Convergence in Western Europe, 1980-2008', American Journal of Sociology 117(4): 1202-1245.

Koopmans, R. and Vliegenthart, R. (2011) 'Media Attention as the Outcome of a Diffusion ProcessA Theoretical Framework and Cross-National Evidence on Earthquake Coverage', European Sociological Review 27(5): 636-653.

Kritz, M. M. (1987) 'International Migration Policies: Conceptual Problems', The International Migration Review 21(4): 947-964.

Kwon, K. H., Chadha, M. and Pellizzaro, K. (2017) 'Proximity and Terrorism News in Social Media: A Construal-Level Theoretical Approach to Networked Framing of Terrorism in Twitter', Mass Communication and Society 20(6): 869-894.

Kydd, A. H. and Walter, B. F. (2006) 'The Strategies of Terrorism', International Security 31(1): 4979.

Legewie, J. (2013) 'Terrorist Events and Attitudes toward Immigrants: A Natural Experiment', American Journal of Sociology 118(5): 1199-1245.

Lippmann, W. (2017) Public Opinion, New York: Routledge.

Lyman, R. and Smale, A. (2015) 'Paris Attacks Shift Europe's Migrant Focus to Security', The New York Times 15 November, available at https://www.nytimes.com/2015/11/16/world/europe/paris-attacks-shift-europes-migrant-focusto-security.html.

Lyons-Padilla, S., Gelfand, M. J., Mirahmadi, H., Farooq, M. and Egmond, M. van (2015) 'Belonging nowhere: Marginalization \& radicalization risk among Muslim immigrants', Behavioral Science \& Policy 1(2): 1-12.

May, P. J., Sapotichne, J. and Workman, S. (2009) 'Widespread Policy Disruption: Terrorism, Public Risks, and Homeland Security', Policy Studies Journal 37(2): 171-194.

McAlexander, R. J. (2019) 'How Are Immigration and Terrorism Related? An Analysis of Right- and Left-Wing Terrorism in Western Europe, 1980-2004', Journal of Global Security Studies Online first.

McCombs, M. (2018) Setting the Agenda: Mass Media and Public Opinion, New York: John Wiley \& Sons.

McCombs, M. and Shaw, D. L. (1972) 'The Agenda-Setting Function of Mass Media', Public Opinion Quarterly 36(2): 176-187.

Merolla, J. L. and Zechmeister, E. J. (2009) Democracy at Risk: How Terrorist Threats Affect the Public, Chicago: University of Chicago Press. 
Mesquita, B. B. de, Smith, A., Siverson, R. M. and Morrow, J. D. (2004) The Logic of Political Survival, Cambridge: The MIT Press.

Neumayer, E., Plümper, T. and Epifanio, M. (2014) 'The "Peer-Effect” in Counterterrorist Policies', International Organization 68(1): 211-234.

Nossek, H. and Berkowitz, D. (2006) 'Telling “Our” Story Through News of Terrorism', Journalism Studies 7(5): 691-707.

Nussio, E. (2018) Attitudinal and Emotional Consequences of Islamist Terrorism, Rochester, NY: Social Science Research Network, available at https://papers.ssrn.com/abstract=3202162 (accessed June 2018).

Nussio, E., Bove, V. and Steele, B. (2019) 'The consequences of terrorism on migration attitudes across Europe', Political Geography.

Plümper, T. and Neumayer, E. (2010) 'Model specification in the analysis of spatial dependence', European Journal of Political Research 49(3): 418-442.

Rudolph, C. (2003) 'Security and the Political Economy of International Migration', American Political Science Review 97(4): 603-620.

Ruhs, M. (2015) The Price of Rights: Regulating International Labor Migration, Princeton: Princeton University Press.

Sandler, T. (2014) 'The analytical study of terrorism: Taking stock', Journal of Peace Research 51(2): $257-271$.

Sandler, T. and Lapan, H. E. (1988) 'The calculus of dissent: An analysis of terrorists' choice of targets’, Synthese 76(2): 245-261.

Schüller, S. (2016) 'The Effects of 9/11 on Attitudes toward Immigration and the Moderating Role of Education', Kyklos 69(4): 604-632.

Selim, G. (2016) 'Approaches for Countering Violent Extremism at Home and Abroad', The ANNALS of the American Academy of Political and Social Science 668(1): 94-101.

Shoemaker, P. J., Lee, J. H., Han, G. and Cohen, A. A. (2007) 'Proximity and Scope as News Values', in E. Devereux (ed.). Media Studies: Key Issues and Debates. Thousand Oaks: SAGE, pp. 231-248.

Spaaij, R. and Hamm, M. S. (2015) 'Endgame? Sports Events as Symbolic Targets in Lone Wolf Terrorism', Studies in Conflict \& Terrorism 38(12): 1022-1037.

Stamps, A. E. (2011) 'Distance Mitigates Perceived Threat', Perceptual and Motor Skills 113(3): 751763.

Stinnett, D. M., Tir, J., Diehl, P. F., Schafer, P. and Gochman, C. (2002) 'The Correlates of War (Cow) Project Direct Contiguity Data, Version 3.0', Conflict Management and Peace Science 19(2): 59-67.

Telhami, S. (2016) 'American attitudes on refugees from the Middle East', Brookings, available at https://www.brookings.edu/research/american-attitudes-on-refugees-from-the-middle-east/ (accessed October 2019).

The Independent (2017) France declares end to state of emergency 719 days after Paris attacks, 31 October, available at http://www.independent.co.uk/news/world/europe/france-state-of- 
emergency-end-terror-attacks-paris-isis-terrorism-alerts-warning-risk-reduced-a8029311.html (accessed December 2018).

Tirman, J. (2004) The Maze of Fear: Security and Migration After 9/11, New York: The New Press.

UNICRI (2014) The European House of Major Events Security: a User Guide for Police Security Planners and Policy Makers, Turin: United Nations Interregional Crime and Justice Research Institute.

Van de Vyver, J., Houston, D. M., Abrams, D. and Vasiljevic, M. (2016) 'Boosting Belligerence: How the July 7, 2005, London Bombings Affected Liberals' Moral Foundations and Prejudice', Psychological Science 27(2): 169-177.

Walgrave, S. and Dejaeghere, Y. (2017) 'Surviving Information Overload: How Elite Politicians Select Information’, Governance 30(2): 229-244.

Westerståhl, J. and Johansson, F. (1994) 'Foreign News: News Values and Ideologies', European Journal of Communication 9(1): 71-89.

Woods, J. and Arthur, C. D. (2017) Debating Immigration in the Age of Terrorism, Polarization, and Trump, New York: Lexington Books.

Worrall, J. L. (1999) 'Focusing Event Characteristics and Issue Accompaniment: The Case of Domestic Terrorism', Criminal Justice Policy Review 10(3): 319-341.

\footnotetext{
${ }^{1}$ Note that our arguments about the role of geographic contiguity to terrorism hinge also on some sense of cultural similarity across borders. In fact, cultural commonalities are likely to be stronger the lower the geographic distance between societies (Guiso et al. 2009). At the same time, cultural proximity likely shapes how media frames security threats and affects the extent to which attacks abroad are covered and how the images are conveyed (Fahmy 2010; Kwon et al. 2017; Nossek and Berkowitz 2006).

${ }^{2}$ Evidence about objective linkages between migration and terrorism is scarce. Recent studies have found at best mixed support for migration inducing terrorism or that more restrictive migration policy lowers terrorism risk (Bandyopadhyay and Sandler 2014; Bove and Böhmelt 2016; Choi 2018; Dreher et al. 2017). Restricting migration policy can even be counterproductive if it creates feelings of discrimination and signals foreign-born populations that they are less welcome (Gillum 2018; Lyons-Padilla et al. 2015). Yet, the few notable cases of migrants staging terrorist attacks, like the Berlin Christmas Market attack in 2016 (Nussio 2018), rise to public consciousness via news media, which makes them salient, although they are not representative of the wider population of terrorism.

${ }^{3}$ Even if political elites control the restrictiveness of migration policy (Statham and Geddes 2006), temporary changes in public opinion still have an impact on their decision-making.

${ }^{4}$ While restricting migration can reduce a country's overall economic growth (Bove and Elia 2017), voters may not be affected directly. Furthermore, there are several important distributional effects and immigration can lower the wage in specific segments of the host country's labour force (see e.g, Borjas, 2014). As such, from an economic perspective, restrictions to immigration do not necessarily translate into costs in voter support.

${ }^{5}$ In Switzerland, a country without major terrorist attacks so far, nearly half of the population saw Islam as a threat to security according to a 2017 survey (Farman and Nussio 2018). In the US, nearly 46 percent of citizens who opposed accepting refugees in 2016 were also concerned about perceived links to terrorism (Telhami 2016).

${ }^{6}$ We expect incumbents to exploit anti-immigrant sentiments regardless of extreme-right competition, as restrictive immigration policies are not only a prerogative of the right-wing parties (Alonso and Fonseca 2012).

${ }^{7}$ This motivation should be most common for right-leaning governments. However, as reported in the appendix, we do not find right-leaning governments to react in a more restrictive manner.

${ }^{8}$ We select OECD countries with a view towards increasing homogeneity among cases. Although perhaps at the expense of being able to generalize our findings to apply to all countries across the globe, our sample comprises states that are rather similar in several aspects at the macro level, e.g., economic development or regime type. Although there are exceptions over time and, e.g., Turkey performed rather poorly in terms of democratic accountability in recent years, only focusing on the states outlined in Figure 1 ensures that our sample represents the population we wish to describe. Note that terrorism data are only available from 1970, yet some of our
} 
control variables are unavailable for a number of countries before 1980. Results are qualitatively the same when we include data for 1970-1980.

${ }^{9}$ The codebook is available at: https://www.imi-n.org/files/data/demig-policy-codebook.pdf .

${ }^{10}$ Our arguments apply to general migration policies and we do not distinguish between types of policies, e.g., regulations and control mechanisms. The appendix presents a robustness check on the share of restrictive policies of all migration policies, however.

${ }^{11}$ The policy-tool variable captures the instrument used to implement the policy measure above and consists of 28 codes, ranging from surveillance technology to work permits. The migrant-category variable identifies the migrant group targeted (e.g., low-skilled workers) whereas the geographical-origin variable includes the origin of the targeted migrant category (e.g., EU citizens.).

${ }^{12} \mathrm{We}$ do not distinguish between national and transnational attacks, but we disaggregate this variable in the appendix.

${ }^{13}$ Stricter immigration policies may lead to more terrorist attacks abroad. If such reverse causality exists, the effect of terrorism abroad on migration policies at home will suffer from downward bias (Epifanio and Plümper 2018). That said, and although we control for a large number of potential confounding factors, our estimates do not necessarily demonstrate a causal mechanism. 